\title{
Relationship of Oral Squamous Cell Carcinoma and Verrucous Carcinoma with Clinical Parameters in A Retrospective Case Study Done in AIIMS, New Delhi
}

\author{
Authors \\ Libin Babu Cherian', Sudheer Arava ${ }^{2}$, MK Singh ${ }^{3}$, Alok Thakar ${ }^{4}$, Julka P K \\ ${ }^{1}$ Junior Resident, Department of Pathology, AIIMS, Ansari Nagar, New Delhi \\ ${ }^{2}$ Associate Professor, Department of Pathology, AIIMS, Ansari Nagar, New Delhi \\ ${ }^{3}$ Professor, Department of Pathology, AIIMS, Ansari Nagar, New Delhi \\ ${ }^{4}$ Associate Professor, Department of Otorhinolaryngology, AIIMS, Ansari Nagar, New Delhi \\ ${ }^{5}$ Professor, Department of Radiation Oncology, AIIMS, Ansari Nagar, New Delhi \\ Corresponding Author \\ Dr Sudheer Arava \\ Associate Professor, Department of Pathology, AIIMS, Ansari Nagar, New Delhi
}

\begin{abstract}
Oral squamous cell carcinoma and verrucous carcinoma are the most common malignant neoplasms of the oral mucosa. The prevalence of these malignancies is quite high in the northern states of India possibly due to tobacco chewing in the form of pan, gutkha, zardar etc. Despite its frequency and multitudes of treatment modalities, the mortality is still on the higher side because of increased rates of early distant metastasis. HPV is also uncommon etiological agent in oral carcinoma and it is more closely related to oropharyngeal cancers than oral cancers, possibly in those areas where two epithelium intersects and basal cells are more exposed. This study relates oral squamous cell carcinoma and verrucous carcinoma with various clinical parameters like age, gender, size of tumor, site of tumor and differentiation of the tumor.

Keywords: $H N P C C, O S C C, V C$.
\end{abstract}

\section{Introduction}

It has been well recognized since the beginning of 19th century that oral cancer is the commonest cancers in India. The peak global prevalence of oral cancers is seen in Srilanka and India occupies the eighth position in the pinnacle ${ }^{(1)}$ Oral squamous cell carcinoma (OSCC) remains the seventh commonest cancer worldwide ${ }^{(2) .}$ It is the seventh commonest cause of death due to cancer in India (global burden of cancer 2013). It is the commonest cancer in males and fifth commonest cancer in females in India (national cancer registry, 2002). Uttarpradesh has reported the maximum brunt of cases and maximum number of deaths in India. Male to female ratio is 4.18:1. Mean age of presentation is 49.73 years. Approximately half of the patients afflicted will die within five years of diagnosis, while surviving patients may be left with severe aesthetic and functional compromise. Beyond prevention, early 
detection is the most crucial determinant for successful treatment, better prognosis, and survival of cancer. Nevertheless, treatment is not always successful. Approximately $40 \%$ of treatment failure rate is seen in patients with OSCC, the most common cause of which is local, regional and distant metastasis. Even in tumorfree surgical margins, a $30 \%$ recurrence rate has been reported. (3)

Presently the incidence of oral and oropharyngeal cancers is increasing in women due to the increasing rates of drinking and smoking amongst modern women in both developing and developed countries. Although there has been a reduction in the overall incidence of HNSCC, an analysis of the National Cancer Institute's Surveillance, Epidemiology and End Results (SEER) data from 1998-2000 found that the incidence of tonsillar cancer increased by 2-3\% annually in males under 60 years of age. A more recent analysis of SEER data from 1973-2013 showed an annual increase in the incidence of oral tongue, palatine tonsil, and base-of-tongue cancers, by $2.1 \%, 3.9 \%$, and $1.7 \%$, respectively, in 20- to 44-year-old white patients, while the incidence of HNSCC at other sites declined. ${ }^{(4)}$ Human papillomavirus (HPV) is one of the most discussed potential risk factors in this group.

In 1941, Friedell and Rosenthal reported a case of a well differentiated variant of squamous cell carcinoma (SCC) in oral cavity and described it as "verrucoid carcinoma". The name "verrucous carcinoma" (VC) was suggested by Lauren Ackerman in his description of 31 similar cases. VC has been described as a papillary, nonmetastasizing, well differentiated malignant neoplasm of squamous epithelium. It is considered as a low grade variant of SCC, closely associated with chewing tobacco and use of snuff, because of which it has been called snuff dipper's cancer. ${ }^{(5)}$ However this is not the sole etiologic factor of $\mathrm{VC}$ as about $16-51 \%$ of oral $\mathrm{VC}$ occurs in persons without tobacco-chewing habit. VC is said to be more closely associated with HPV than squamous cell carcinoma ${ }^{(6)}$. The endophytic growth that is a hallmark of this tumor is due to its resilient basement membrane that probably acts as an effective barrier to prevent the carcinomatous growth. Verrucous carcinoma is a low grade variant of SCC, with less aggressive clinical course and good prognosis compared to conventional SCC. This difference in clinical behaviour between VC and SCC may be due to the high expression of p16 and p27 in $\mathrm{VC}$ compared to SCC, while the later shows strong reactivity for Ki67 and p53.

\section{Aims, Objectives, Materials and Methods}

Evaluation of cases of oral squamous cell carcinoma and verrucous carcinoma admitted in AIIMS, New Delhi between 2012-2013 with respect to various parameters like age, sex, tumor differentiation, site of tumor and size of tumor.

Inclusion Criterion of the study includes previously untreated naïve surgically excised cases of oral SCCs, diagnosed initially by a biopsy(s) at AIIMS and adequate material available in the paraffin blocks for IHC. Exclusion Criterion of the study includes histological section showing predominately necrosis andif relevant clinical history, paraffin blocks and adequate sections were not available. Requisite clinical information of all the selected cases were obtained from medical records of Institute Rotatory Cancer Hospital (IRCH), AIIMS

For all retrospective cases clinical data were retrieved from the patient files in clinical record sections (Institute Rotary Cancer Hospital (IRCH) and ENT department, All India Institute of Medical Sciences.) and the corresponding paraffin blocks were retrieved from the archives of histopathology section. (Department of Pathology, All India Institute of Medical Sciences.). The corresponding excision biopsy material is processed in an automated histokinetic processor and paraffin blocks were prepared. Histopathological sections of 4-5 micron thickness were cut from prospective and retrospective cases and routine hematoxylin and eosin staining was done for definitive diagnosis, histological 


\section{JMSCR Vol||05||Issue||12||Page 31801-31807||December}

subtyping and staging of the tumor. The Haematoxylin and Eosin (H\&E) stained slides were reviewed and a concordant agreement was established for the confirmation of the diagnosis (which includes subtyping and differentiation of tumor- using broders classification), by two expert oral histopathologists. Representative blocks of formalin-fixed paraffin embedded tissues were selected for each case. Five micron thick sections were cut from the blocks and stained with Haematoxylin and Eosin for definitive histological diagnosis and tumor subtyping. The patients were divided into following groups Group 1: Oral squamous cell carcinoma without lymph node metastasis ( $n=25)$ Group 2: Oral squamous cell carcinoma with lymph node metastasis $(n=25)$ Group 3: Verrucous carcinoma $(n=25)$

\section{Results}

\section{Distribution of Cases:}

A total of 75 cases of primary oral squamous cell carcinoma (OSCC) and verrucous carcinoma (VC) were studied over a period of 3 years (January 2012- December 2013) and the cases were grouped as follows.

Table 1.1: Case Distribution

\begin{tabular}{|l|c|}
\hline Cases & $\begin{array}{c}\text { Number of cases } \\
(\%)(\mathrm{n}=75)\end{array}$ \\
\hline $\begin{array}{l}\text { Group I- Primary OSCC without } \\
\text { lymph node metastasis (SCCWOM) }\end{array}$ & $25(33.33 \%)$ \\
\hline $\begin{array}{l}\text { Group II- Primary OSCC with lymph } \\
\text { node metastasis (SCCWM) }\end{array}$ & $25(33.33 \%)$ \\
\hline Group III- Verrucous carcinoma (VC) & $25(33.33 \%)$ \\
\hline
\end{tabular}

25 control cases were taken from the surgically excised tumor free margins of the cases. Smoking/pan chewing history was found in $68 \%$ patients of verrucous and $76 \%$ patients of squamous cell carcinoma

\section{Clinical Parameters}

\section{Age distribution}

The minimum age observed in OSCC was 27 years and maximum age was 72 years with a mean age of 46.92 years. Most cases were in the fourth decade, followed by third and fifth decade. The minimum age observed in $\mathrm{VC}$ was 25 years and maximum age was 79 years with a mean age of 47.44 years. Most of the cases of VC were between $4^{\text {th }}$ and $7^{\text {th }}$ decade.

Table 1.2: Age distribution in squamous cell carcinoma and verrucous carcinoma

\begin{tabular}{|l|c|c|}
\hline $\begin{array}{l}\text { Age group } \\
\text { (years) }\end{array}$ & $\begin{array}{c}\text { Squamous cell } \\
\text { carcinoma } \\
\text { (Group I + Group II) } \\
(\mathrm{n}=50)\end{array}$ & $\begin{array}{c}\text { Verrucous } \\
\text { Carcinoma }(\%) \\
(\text { Group III) } \\
(\mathrm{n}=25)\end{array}$ \\
\hline 20-29 years & $3(6.00 \%)$ & $0(0 \%)$ \\
\hline 30-39 years & $13(26.00 \%)$ & $4(16.00 \%)$ \\
\hline 40-49 years & $16(34.00 \%)$ & $6(24.00 \%)$ \\
\hline 50-59 years & $9(18.00 \%)$ & $6(24.00 \%)$ \\
\hline 60-69 years & $7(14.00 \%)$ & $6(24.00 \%)$ \\
\hline $70-79$ years & $2(4.00 \%)$ & $3(12.00 \%)$ \\
\hline
\end{tabular}

Table 1.3: Mean age group in SCC and VC

\begin{tabular}{|c|c|}
\hline Study group & Mean age group \\
\hline $\begin{array}{l}\text { Squamous cell carcinoma } \\
\text { (Group I + Group II) } \\
(\mathrm{n}=50)\end{array}$ & $\begin{array}{c}46.92 \text { years } \\
\text { Lower limit- } 27 \text { years } \\
\text { Upper limit- } 72 \text { years }\end{array}$ \\
\hline $\begin{array}{l}\text { Verrucous carcinoma } \\
\text { (Group III) } \\
(\mathrm{n}=25)\end{array}$ & $\begin{array}{c}\text { 47.44 years } \\
\text { Lower limit- } 25 \text { years } \\
\text { Upper limit- } 79 \text { years }\end{array}$ \\
\hline
\end{tabular}

Figure 1.1 Bar diagram showing age distribution in SCC and VC

\section{Chart Title}

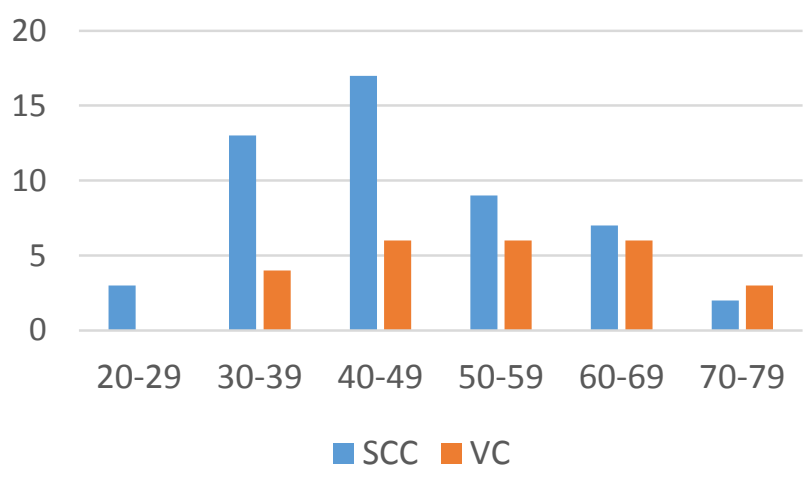

Majority of the patients in SCC (68\%) and VC $(84 \%)$ were $\geq 40$ years of age.

Table 1.4: Age category in Squamous and Verrucous carcinoma

\begin{tabular}{|l|c|c|}
\hline Age category & $\begin{array}{c}\text { Squamous cell } \\
\text { Carcinoma (\%) } \\
\text { (Group I + Group II) } \\
(\mathrm{n}=50)\end{array}$ & $\begin{array}{c}\text { Verrucous } \\
\text { Carcinoma (\%) } \\
(\text { Group III) } \\
(\mathrm{n}=25)\end{array}$ \\
\hline$<40 \mathrm{yrs}$ & $16(32 \%)$ & $4(16 \%)$ \\
\hline$>/=40 \mathrm{yrs}$ & $34(68 \%)$ & $21(84 \%)$ \\
\hline
\end{tabular}




\section{JMSCR Vol||05||Issue||12||Page 31801-31807||December}

Figure 1.2: Bar diagram showing age distribution in $\mathrm{SCC}$ and $\mathrm{VC}$

\section{Chart Title}

50

40

30

20

10

0

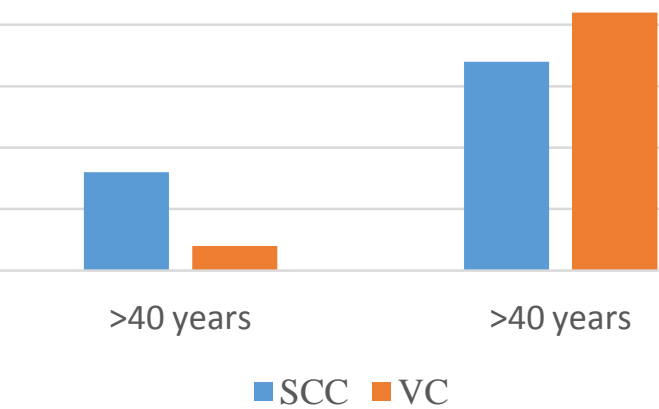

\section{Sex distribution}

Male preponderance was observed in both SCC and VC with a M:F ratio of $4: 1$ in SCC and 24:1 in $\mathrm{VC}$ respectively.

Table 1.5: Sex distribution in SCC and VC

\begin{tabular}{|l|c|c|}
\hline Sex & $\begin{array}{c}\text { Squamous cell } \\
\text { carcinoma (\%) } \\
\text { (Group I + Group II) } \\
(\mathrm{n}=50)\end{array}$ & $\begin{array}{c}\text { Verrucous } \\
\text { Carcinoma (\%) } \\
\text { (Group III) } \\
(\mathrm{n}=25)\end{array}$ \\
\hline Male & $40(80 \%)$ & $24(96 \%)$ \\
\hline Female & $10(20 \%)$ & $1(4 \%)$ \\
\hline $\begin{array}{l}\text { Male to female } \\
\text { ratio (M:F) }\end{array}$ & $4: 1$ & $24: 1$ \\
\hline
\end{tabular}

Figure 1.3: Bar diagram showing sex distribution in SCC and VC

\section{Chart Title}

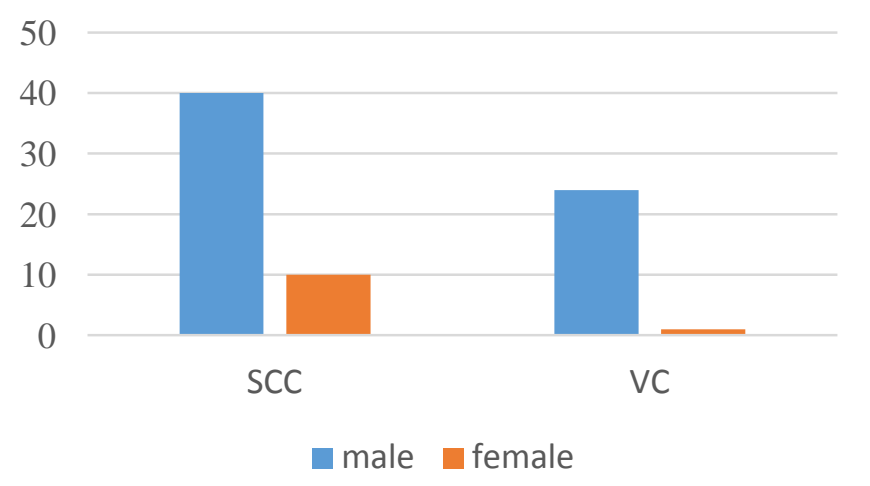

\section{Site distribution}

The most common anatomic location of tumor in SCC was Gingivobuccal sulcus (54\%) whereas it was buccal mucosa $(48 \%)$ in VC.
Table 1.6 Site distribution in SCC and VC

\begin{tabular}{|l|c|c|c|}
\hline & $\begin{array}{c}\text { SCCWOM } \\
(\text { Group I) } \\
(\mathrm{n}=25)\end{array}$ & $\begin{array}{c}\text { SCCWM } \\
(\text { Group II) } \\
(\mathrm{n}=25)\end{array}$ & $\begin{array}{c}\text { VC } \\
(\text { Group III) } \\
(\mathrm{n}=25)\end{array}$ \\
\hline Buccal mucosa & $5(20 \%)$ & $4(16 \%)$ & $12(48 \%)$ \\
\hline Tongue & $7(28 \%)$ & $6(24 \%)$ & $10(4 \%)$ \\
\hline $\begin{array}{l}\text { Gingivo-buccal } \\
\text { sulcus }\end{array}$ & $12(48 \%)$ & $15(60 \%)$ & $3(12 \%)$ \\
\hline Lip & $1(4 \%)$ & $1(4 \%)$ & $0(0 \%)$ \\
\hline
\end{tabular}

Figure 1.4: Bar diagram showing site distribution in SCC and VC

\section{Chart Title}

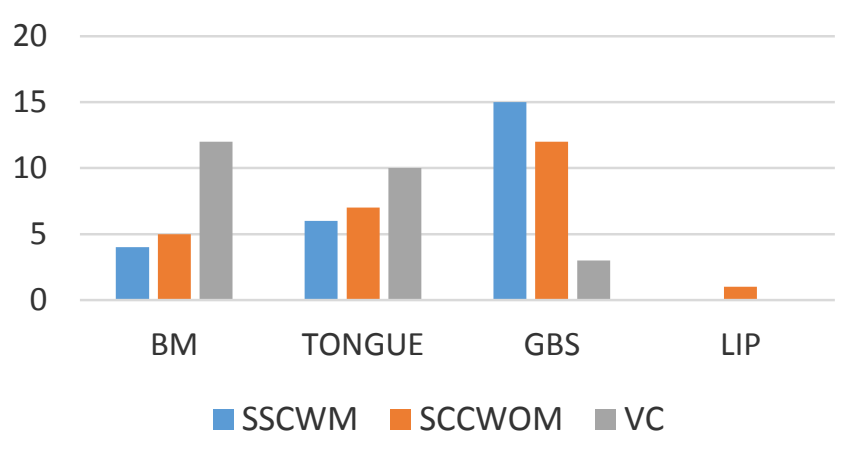

\section{Tumor stage}

Majority of cases of SCCWM (Group II) were presented in later stage whereas SCCWOM (group I), and VC (Group III) were in presented in the early stage.

Table 1.7 Stage distribution in SCC and VC

\begin{tabular}{|l|c|c|c|}
\hline & $\begin{array}{c}\text { SCCWOM } \\
(\text { Group I) } \\
(\mathrm{n}=25)\end{array}$ & $\begin{array}{c}\text { SCCWM } \\
(\text { Group II) } \\
(\mathrm{n}=25)\end{array}$ & $\begin{array}{c}\text { VC } \\
(\text { Group III) } \\
(\mathrm{n}=25)\end{array}$ \\
\hline Stage 1 & $17(68 \%)$ & $0(0 \%)$ & $15(60 \%)$ \\
\hline Stage 2 & $6(24 \%)$ & $0(0 \%)$ & $9(36 \%)$ \\
\hline Stage 3 & $1(4 \%)$ & $8(32 \%)$ & $1(4 \%)$ \\
\hline Stage 4 & $0(0 \%)$ & $18(72 \%)$ & $0(0 \%)$ \\
\hline
\end{tabular}

Figure 1.5: Bar diagram showing stage distribution in SCC and VC

\section{Chart Title}

\section{0}

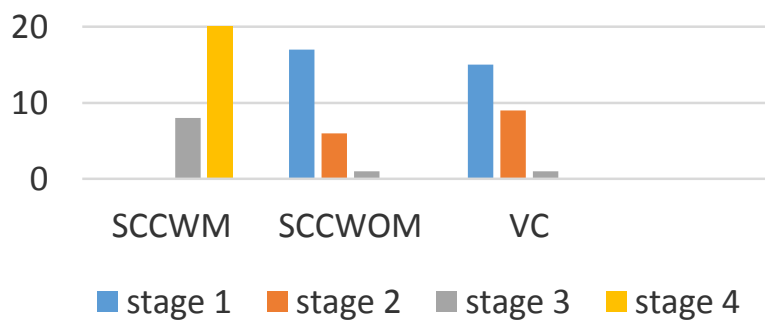




\section{JMSCR Vol||05||Issue||12||Page 31801-31807||December}

\section{Tumor size}

Most of the cases of SCC were presented as ulcerated or ulceroproliferative growth whereas $\mathrm{VC}$ on the other hand, presented as fine papillary projections over the mucosa. Majority of cases with tumor size $>4 \mathrm{~cm}$ were noted in SCCWM whereas cases with tumor size $<4 \mathrm{~cm}$ were encountered in SCCWOM and VC. (Table 5.8)

Table 1.8: Tumor Size in SCC and VC

\begin{tabular}{|l|c|c|c|}
\hline Size & $\begin{array}{c}\text { SCCWOM } \\
\text { Group I } \\
(\mathrm{n}=25)\end{array}$ & $\begin{array}{c}\text { SCCWM } \\
\text { Group II } \\
(\mathrm{n}=25)\end{array}$ & $\begin{array}{c}\text { VC } \\
\text { Group III } \\
(\mathrm{n}=25)\end{array}$ \\
\hline$<4 \mathrm{~cm}$ & $21(84 \%)$ & $11(44 \%)$ & $22(88 \%)$ \\
\hline$>/=4 \mathrm{~cm}$ & $4(16 \%)$ & $14(56 \%)$ & $3(12 \%)$ \\
\hline
\end{tabular}

Figure 1.6: Bar diagram showing tumor size in $\mathrm{SCC}$ and $\mathrm{VC}$

\section{Chart Title}

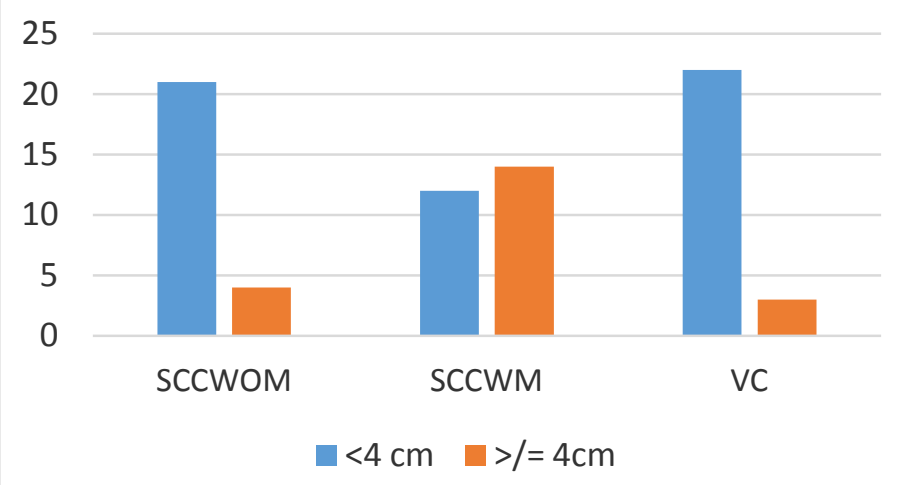

\section{Tumor differentiation}

Majority of the cases of SCC were moderately differentiated type (54\%) followed by well differentiated type (46\%). None of the cases showed poorly differentiated morphology (Table 5.9).

Table 1.9: Tumor differentiation in SCCWOM and SCCWM

\begin{tabular}{|l|c|c|}
\hline & WDSCC & MDSCC \\
\hline $\begin{array}{l}\text { SCCWOM } \\
\text { (Group I) }\end{array}$ & $13(52 \%)$ & $12(48 \%)$ \\
\hline SCCWM (Group II) & $10(40 \%)$ & $15(60 \%)$ \\
\hline
\end{tabular}

Figure 1.7: Bar diagram showing tumor differentiation in SCC and VC

\section{Chart Title}

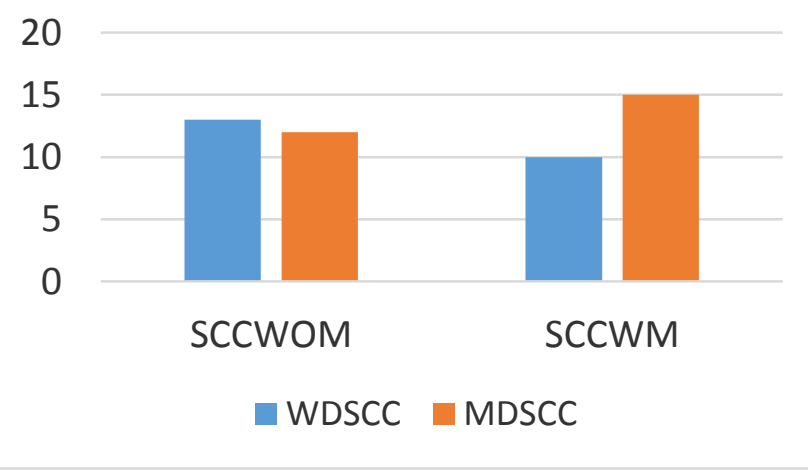

\section{Discussion and Summary}

Oral squamous cell carcinoma (OSCC) remains the tenth most common tumor in male patients worldwide with an incidence of 264,000 newly diagnosed patients and 128,000 deaths worldwide in 2008. The best known risk factors are tobacco, alcohol, and chewing betel quid. Mean age of oral SCC is 46.92 years and oral verrucous carcinoma is 47.44 years revealing the most common presentation is between 4th and 5th decade of life. This finding is in concordance with the studies done by Doshi Neena et al (2011), McCoy et al (1981), Oliveira et al (2006) and Walvekar et al (2009). ${ }^{(6)}$ Male: Female ratio in OSCC and in verrucous carcinoma were $4: 1$ and $24: 1$ respectively, showing male preponderance in both the groups. Similar results were also found in studies done by Oliveira et al (2006) Fillies et al (2007) Walvekar et al (2009), Rekha and Angadi et al (2010),. The male preponderance in both OSCC and verrucous carcinoma is due to more tobacco chewing and simultaneous consumption of alcoholic beverages in males as compared to females. Although oral cancers in females are in a rise in developed countries due to oral malsexual practices and smoking, such a hype in frequency has not yet been reported in developing countries like India and south East Asia. The notion was in accordance with our study.

Most common site of OSCC was gingivobuccal sulcus $(54 \%)$ followed by tongue $(26 \%)$, buccal mucosa (18\%) and lip (2\%) whereas most 
common sites of VC was buccal mucosa (48\%), followed by gingivo buccal sulcus (12\%) and tongue (4\%). This is in concordance with various studies done by Mc coy et al (1981); Walvekar et al (2009); Lin et al (2011). However, there are few studies showing discordant results as Agarwal and Rajderkar et al (2012), Mathew Iype et al (2001) and Oliveira et al (2006) which showed tongue, buccal mucosa, lower lip and hard palate as the most common sites of involvement in OSCC respectively. ${ }^{(7)}$ This is most probably due to varying modes of consuming tobacco and interplay of other factors like genetics and immunodeficiency. Explanation for involvement of gingivobuccal sulcus as the most common site is probably due to placement of tobacco quid in this area causing chronic irritation with subsequent development of dysplasia and invasive carcinoma in Asian population. Lip is the most common site of involvement in western population as cigarette smoking is the most common mode of tobacco use. UV rays from sunlight in fair skinned people may act as a confounding factor in development of lip SCC in western countries. Most SCCWM presented in later stages of disease, most common being stage IV $(72 \%)$ and squamous cell carcinoma without metastasis in stage I. In total of all squamous cell carcinomas most of them where in stage III and stage IV. Compared to Verrucous carcinoma which presented in early stages of disease, and most common being Stage I $(60 \%)$. This reveals that OSCC are more aggressive with high metastatic potential and present at later stages when compared to verrucous carcinoma. This was in concordance with study by Voldberg BR et al in which $86.66 \%$ of oral squamous cell carcinomas with metastasis presented with stage IV disease $(88.6 \%)$ compared to squamous cell carcinoma without metastasis which usually presented with stage I and stage II disease. ${ }^{(8)}$ Chang KY et al (2001) showed that verrucous carcinomas usually presented with lower stages of disease usually stage I (98.99\%). ${ }^{(9)}$ Only $2 \%$ cases presented with stage II disease and almost never metastasized to lymph nodes. Majority of cases with tumor size $>4 \mathrm{~cm}$ were noted in SCCWM whereas tumor size $<4 \mathrm{~cm}$ were encountered in SCCWOM and VC. Cut off for tumor size of 4 $\mathrm{cm}$ was taken as there is difference in treatment options; Tumors less than $4 \mathrm{~cm}$ usually undergo surgery with supraomohyoid neck dissection whereas tumors more than $4 \mathrm{~cm}$ are treated with surgery and supraomohyoid neck dissection followed by chemo radiation. This was in accordance with the study done by Muir et al (1997) and Noble topham et al (2002) who accentuated the relationship of tumor size with oral cancer histological subtypes ${ }^{(10)}$ Verrucous carcinoma presents as a small verrucous growth of approximately $2.23 \mathrm{~cm}$ compared to squamous cell carcinomas which usually presents with an ulceroproliferative growth more than $2.55 \mathrm{~cm}$ on an average.

\section{References}

1. Binnie WH, Rankin KV, Mackenzie IC. Etiology of oral squamous cell carcinoma. J Oral pathology 1983; 12: 11-29.

2. Chen J, Katz RV, Krutchkoff DJ. Eisenberg E, lip cancer incidence trends in Connecticut 1935-1985; Cancer 1992; 70: 2025-2030.

3. Douglas CW, Gammon MD. Reassessing the epidemiology of lip cancer. Oral surgery oral med oral pathology 1984; 57, 631-642.

4. Binnie WH, Rankin KV. Epidemiological and diagnostic aspects of oral squamous cell carcinomas. J oral pathology 1984; 13 : 333-341.

5. Chen J, Katz RV, Krutchkoff DJ, intra oral SCC: epidemiological patterns in Connecticut from 1935 to 1985. Cancer 1990; 66:1288-1296.

6. Walvekar K, Danielle J, Day TA .oral cancer and precancerous lesions. CA Cancer J Clinical 2009; 52:195-215.

7. Mathew Iype, Oliviera M, Reed K, Ravi Kumar TS, Gifford RRM, Grage TB. The 
association of faconi's anaemia and squamous cell carcinoma. Cancer 2001; 52 926-928.

8. Voldberg BR, Rich AM, Radden BG. Squamous cell carcinoma of oral mucosa. A review of 244 cases in Australia. J oral pathology 1984; 13:459-471.

9. Chang M, Forastiere A, Koch W, Trotti A, Sidransky D. head and neck cancer. N Engl J Med 2001; 345: 2001.

10. Muir C, Noble Topham, Duncan LD, Weiland I. Upper aerodigestive tract cancers. Cancer 2003; 75,147-153. 